\title{
Financial synergy in mergers and acquisitions. Evidence from Saudi Arabia
}

\author{
Basmah, Al Qudaiby \\ Rahatullah, Muhammad K.
}

- RECEIVED: 27 OCTOBER 2013

- accepted: I5 january 2014

\begin{abstract}
Businesses today consider mergers and acquisitions to be a new strategy for their company's growth. Companies aim to grow through increasing sales, purchasing assets, accumulating profits and gaining market share. Thus; the best way to achieve any of the above-mentioned targets is by getting into either a merger or an acquisition. As a matter of fact, growth through mergers and acquisitions has been a critical part of the success of many companies operating in the new economy. Mergers and acquisitions are an important factor in building up market capitalization. Based on three structured interviews with major Saudi Arabian banks it has been found that mergers motivated by economies of scale should be approached cautiously. Similarly, companies should also approach vertical mergers cautiously as it is often difficult to gain synergy through a vertical merger. Firms should seek out mergers that allow them to acquire specialized knowledge. It has also been found that firms should look for mergers that increase market power whilst avoiding unrelated mergers or conglomerate mergers.
\end{abstract}

\section{Keywords:}

Synergy, Mergers and Acquisitions, Saudi Arabia

\section{JEL classification:}

N25. 


\title{
Sinergia financiera en fusiones y adquisiciones. Evidencia en Arabia Saudí
}

\author{
Basmah, Al Qudaiby \\ Rahatullah, Muhammad K.
}

\section{Resumen}

Las fusiones y adquisiciones son consideradas hoy en día como una nueva estrategia para el crecimiento de las empresas. Éstas, tratan de crecer a través del incremento de las ventas, la compra activos, la acumulación de beneficios y el aumento de la cuota de mercado. Por lo tanto, la mejor manera para alcanzar cualquiera de los objetivos antes mencionados es mediante una fusión o una adquisición. De hecho, el crecimiento vía fusiones y adquisiciones ha sido una parte fundamental del éxito de muchas de las empresas que operan en la nueva economía. Las fusiones y adquisiciones son un factor importante en la creación de valor de mercado. Sobre la base de tres entrevistas estructuradas con los principales bancos de Arabia Saudita, se ha encontrado que las fusiones motivadas por las economías de escala deben abordarse con precaución. Del mismo modo, las empresas también deben enfocar cautelosamente las fusiones verticales, porque a menudo es difícil obtener sinergias mediante una fusión de este tipo por lo que deben tratar de buscar fusiones que les permitan adquirir conocimiento especializado. Otro resultado de esta investigación es que las empresas deben tratar de lograr fusiones que incrementen el poder de mercado, evitando pues fusiones relacionadas o conglomeradas.

\section{Palabras clave:}

Sinergia, fusiones y adquisiciones, Arabia Saudí. 


\section{Introduction}

There is a major difference between mergers and acquisitions. Mergers occur between similarly sized companies and the collaboration is "friendly" between both companies. However, Acquisitions often occur between differently sized companies and the partnership is usually forced and hostile.

Wheelen and Hunger (2009) define a merger as a transaction involving two or more corporations in which stock is exchanged but in which only one corporation survives. In other words, the two companies become one and the name for the corporation becomes composite and is derived from the two original names. Furthermore, an acquisition is the purchase of a company that is completely absorbed as an operating subsidiary or division of the acquiring corporation (Wheelen and Hunger, 2009). The authors also state that hostile acquisitions are called takeovers.

The main reason for firms entering into mergers and acquisitions $(M \& A)$ is to grow, and companies grow to survive (Akinbuli, 2012). Growth strategies expand the company's activities and add to its value since larger firm have more bargaining power than smaller ones. A firm sustaining growth will always have more opportunities for advancement, promotions and more jobs to offer people (Wheelen and Hunger, 2009). In general, mergers and different types of acquisitions are performed in the hope of realizing an economic gain. For such a business deal to take place, the two firms involved must be worth more together than each was apart.

A few of the prospective advantages of $M \& A$ include achieving economies of scale, combining complementary resources, garnering tax advantages, and eliminating inefficiencies. Other reasons for considering growth through acquisitions contain obtaining proprietary rights to products or services, increasing market power by purchasing competitors, shoring up weaknesses in key business areas, penetrating new geographic regions, or providing managers with new opportunities for career growth and advancement (Brown, 2005).

Many firms choose M\&A as a tool to expand into a new market or new area of expertise since it is quicker and cheaper than taking the risk alone. Furthermore, M\&A happen when senior executives feel enthusiastic and excited about a potential deal ; the idea of successfully pursuing and taking over another company before the company s competitors are able to do so. Competition in a growing industry drives firms to acquire others. In fact, a successful merger between companies increases benefits for the entire corporation. 
However, failures also occur in M\&A as indicated by Haberbserg and Rieple (2001) and Akinbuli (2012). They showed that 50\% of acquisitions are unsuccessful; they increase market power but do not necessarily increase profits. Brown (2005) explains the reasons for the high failure rate of $M \& A$ as follows:

(a) Over-optimistic assessment of economies of scale. Economies of scale are usually achieved at certain business size. However, expansion beyond the optimum level results in disproportionate cost disadvantages that lead to various diseconomies of scale.

(b) Inadequate preliminary investigation combined with an inability to implement the amalgamation efficiently. Resistance to change and the inability for the acquired company to manage change well is a main reason for failure due to the resistance of the employees and management of both companies involved.

(c) Insufficient appreciation of the personnel problems, which will arise, is due mainly to the differing organizational cultures in each company.

(d) Dominance of subjective factors such as the status of the respective boards of directors.

Therefore, drafting careful plans before and after the merger is a necessity that should not be overlooked. Some companies find the solution in hiring a change manager who will add value and better manage the transition of the "marriage between both companies" (Brown, 2005).

\section{Synergy in M\&A and financial synergy}

This section discusses the literature review in order to identify the importance of acquiring financial synergy in the M\&A.

\subsection{Synergy in M\&A}

Synergy, as defined in the business dictionary, is the state in which two or more agents, entities, factors, processes, substances, or systems work together in a particularly fruitful way that produces an effect greater than the sum of their individual effects. Synergy is the magic force that allows for enhanced cost efficiencies of the new business. Synergy takes the form of revenue enhancement and cost savings (Mergers and acquisitions: Definition, n.d.). 
Synergy is also expressed as an increase in the value of assets as a result of their combination. Expected synergy is the justification behind most business mergers. For example, the 2002 combination of Hewlett-Packard and Compaq was designed to reduce expenses and capitalize on combining Hewlett-Packard's reputation for quality with Compaq's impressive distribution system (Synergy Business Definition, n.d.).

Through research it has been noted that synergy is the concept that two businesses will generate greater profits together than they could separately (Wheelen and Hunger, 2009). Synergy is said to exist for a divisional corporation if the return on investment of each division is greater than what the return would be if each division were an independent business (Wheelen and Hunger, 2009). In order to succeed cooperation between the partners is the basic ingredient for achieving growth through synergy (Rahatullah, 2010). This requires partners to build trust, commitment, and secure consensus, to achieve their targets (Gronroos, 1997; Ring and Van-de-Ven, 1994).

Synergy can take several forms. According to Goold and Campbell (1998) synergy is demonstrated in six ways: benefiting from knowledge or skills, coordinated strategies, shared tangible resources, economies of scale, gaining bargaining power over suppliers and creating new products or services.

$M \& A$ result in the creation of synergies, the sharing of manufacturing facilities, software systems and distribution processes. This type of synergy is referred to as operational synergy and is seen mostly in manufacturing industries. Another motive for forming an acquisition is gaining greater financial strength by purchasing a competitor, which increases market share. The aim of mergers and acquisitions is to achieve improvement for both companies and produce efficiency in most of the company's operations. (Haberberg and Rieple, 2001).

However, Brown (2005) summarizes the sources of synergy that result from M\&A under the following headlines:

\section{Operating economies which include:}

(a) Economies of scale: Horizontal mergers (acquisition of a company in a similar line of business) are often claimed to reduce costs and therefore increase profits due to economies of scale. These can occur in the production, marketing or finance divisions. Note that these gains are not expected automatically and diseconomies of scale may also be experienced. These benefits are sometimes also claimed for conglomerate mergers (acquisition of companies in unrelated areas of business) in financial and marketing costs. 
(b) Economies of vertical integration: Some acquisitions involve buying out other companies in the same production chain. For example, a manufacturer buys out a raw material supplier or a retailer. This can increase profits through eliminating the middleman in the supply chain.

(c) Complementary resources: It is sometimes argued that by combining the strengths of two companies a synergistic result can be obtained. For example, combining a company specializing in research and development with a company strong in the marketing area could lead to gains. Combining the expertise of both firms would benefit each company through the gained knowledge and skills that individually they lack.

(d) Elimination of inefficiency: If either of the two companies had been badly managed; its performance and hence its value can be improved by the elimination of inefficiencies through M\&A. Improvements could be obtained in the areas of production, marketing and finance.

2. Market power; Horizontal mergers may enable the firm to obtain a degree of monopoly power which could increase its profitability. Coordinated strategies between both companies will lead the entire organization in gaining competitive advantage. Gaining bargaining power over suppliers is realized since the company is larger in size after the merger.

3. Financial gains; Companies with large amounts of surplus cash may see the acquisition of other companies as the best application for these funds. Shared tangible resources such as sharing a bigger building, more office supplies, equipment, manufacturing facilities and research and design labs will also lead to a reduction in costs translated into better financial performance. McNeil (2012) identifies that the shareholders of a business under M\&A process may benefit from the sale of their stocks, this is especially true if the M\&A is with a better, bigger and more reputable prospective partner.

4. Others; such as surplus management talent, meaning that companies with highly skilled managers can make use of their qualified personnel only if they have problems to solve. The acquisition of inefficient companies allows for maximum utilization of skilled managers. Incorporating the efforts of both management teams will drive the creation of innovative products or services.

The synergy factor prevails in the M\&A when the firms produce a greater return than the two individual firms owing to reasons such as improvements in efficiency and an increase in market power for the merged or acquired firms (Berkovitch and Narayana, 1993). 


\subsection{Financial synergy}

As defined by Knoll (2008), financial synergies are performance advantages gained by controlling financial resources across businesses of firms. There exist four types of financial synergies, which are:

1. Reduction of corporate risk: Reduction of corporate risk is increasing the risk capacity of the overall firm, which means the ability of the firm to bear more risk. Meaning that by increasing the risk capacity the shareholders will invest more in the company and the firm will gain benefits such as coinsurance effects.

2. Establishment of internal capital market: Establishing internal capital gains means that the firm will decrease its financing costs and will increase financial flexibility which results in the company having higher liquidity and the ability to pay its creditors easily.

3. Tax advantages: Tax advantages by reducing the tax liabilities of the firm using the losses in one business to offset profits in the other business referred to as "profit accounting".

4. Financial economies of scale: Financial economies of scale reducing transaction cost in issuing debt and equity securities (Knoll, 2008).

\section{Methodology and results}

For this project, the method of interviews was used due to it being the most appropriate way to gather information about the interpretation of events, as to why some mergers produce synergy while others do not; and to understand the reasons why companies enter into mergers. In Saudi Arabia it is difficult to secure responses from senior executives. Approaching such a person is not only difficult protocol wise but there are bureaucratic hurdles. The quantitative analysis is more suitable for large scale data collection (Denzin and Lincoln, 1997). Whereas, qualitative research provides the researcher with the perspective of target audience members through captivation and direct interaction with the people under study (Glesne and Peshkin, 1992). These methods help to comprehend what others perceive of a certain phenomenon, postulates Creswell (1994).

The planned interview method was to use a structured interview. In a structured interview, the researcher knows in advance what information is needed and asks a predetermined set of questions (Sekaran and Bougie, 2009). The same questions 
are asked of all interviewees, which allows for better comparison of the responses than unstructured interviews, where the interviewees are asked different questions. The structured interview process does allow the researcher to ask different follow up or probing questions based on the interviewee's response. This allows the interviewer to identify new factors and gain a deeper understanding of the topic (Sekaran and Bougie, 2009).

Since the interviewees were located in different parts of Saudi Arabia the interviews were scheduled in advance and conducted face to face. The data was gathered by taking notes during the interviews, which were not recorded as that may have seemed too intrusive.

When conducting interviews it is important to conduct them in a manner that is free of bias or inaccuracies. According to Sekaran and Bougie (2009), bias can be introduced by the interviewer, interviewee or the situation. Interviewers can introduce bias by distorting the information that they hear so it aligns with their expected responses to the question or through simple misunderstandings. To prevent this, the respondents' answers were summarized back to them before moving on to the next question. Interviewees can introduce bias if they do not like the interviewer or if they phrase the answers to be biased towards what they think the interviewer wants to hear. Since the interviewees were obtained through referrals, it is highly unlikely that they gave false responses. Also, the basic area of research was discussed with the interviewees, but no hypothesis was advance to them, such that they would skew their answers to what they though the interviewer wanted to hear.

Three companies were interviewed and asked a specific set of questions (see Appendix). There are numerous reasons to interview three companies in Saudi Arabia. These are the following:

- The M\&A in Saudi Arabia are normally carried out by large size companies.

- It is difficult to reach out to the senior managers to discuss such issues.

- The officers are also tied by company confidentiality rules to not divulge information.

- The number of M\&A is also significantly less in comparison with other countries.

- The researchers, using diverse resources including personal contacts and formal requests, were able to reach out to three of the major companies of the Kingdom.

An interview was conducted with National Commercial Bank (NCB) NCB is an international bank headquartered in Saudi Arabia and engaged in personal, business and private banking, and wealth management (NCB, 2011). Another interview was done with Samba Financial Group. Samba is also an international bank 
headquartered in Saudi Arabia that is engaged in personal and business banking (Samba, 2011). The third company that was interviewed was Savola Holding Company, which is headquartered in Jeddah, Saudi Arabia and is engaged in the food industry. Through subsidiary companies, Savola is engaged in the manufacturing of vegetable oils, dairy products and food retailing operations both in Saudi Arabia and other international markets. Due to strict confidentiality of the companies interviewed, the names of the people will not be mentioned or their titles. This was the most important condition in order to conduct these interviews.

Each of the three companies has been involved in significant mergers. NCB's most significant merger was when it acquired a Turkish bank, Turkiye Finans Katilm Bank in 2008. Samba's most significant merger was its acquisition of Cairo Bank in 1999. Savola's most significant acquisition was its acquisition of Al-Marai in 1991.

NCB has engaged in four mergers overall and three international mergers. In addition to its acquisition of the Turkish bank, it acquired Estate Capital Holdings, The Capital Partnership Group Limited and NCB Capital. The acquisition of the Turkish bank was considered its most successful acquisition because it allowed NCB to expand into a new international market with strong growth.

While NCB does not consider any of its acquisitions to be a failure, it has recognized losses through goodwill impairment, even in the Turkish bank acquisition. Samba's most prominent M\&A has been with Cairo bank of Egypt.

Savola has engaged in about 10 mergers including a few international mergers. It considers its acquisition of Panda (a supermarket chain) in 1998 to be its most successful because it allowed Savola to gain a major presence in the food retailing market and increases revenues significantly. Savola has had a couple of mergers that it considered to be failures. One such example was when it acquired a real estate company in Jordan. This company was outside Savola's core business and outside its home country. Savola's learning from this failure was not to invest outside its core business in a foreign country as there was no ability to create any value through this merger and it was investing in a country that it did not know as well as its home country. Another failed merger occurred when it acquired an edible oil company in Kazakhstan. This merger failed because even though the acquired company had good fundamentals, the value creation mechanisms were quite different between the two companies.

Strategic motivations for mergers were discussed with the companies and Samba provided details. One motivation is to increase lines of business. Another motivation is to move into a new geographic area. In many cases when expanding into a new 
country, it is easier to acquire an existing business than try to start a new one. Another motivation is to increase market share.

Particularly in a mature industry, a company can gain market share quickly through an acquisition, while it is usually a slow process to gain market share organically in an incremental manner.

All the companies tried to achieve company growth and synergy in their mergers.

The criteria and selection process for mergers were also discussed with the companies. Savola worked with financial institutions to identify acquisition target companies. Savola looked for companies that were among the leaders in their respective markets. Savola believed that companies that were leaders generally had good processes and were well managed, so their operations would be good to acquire. After the failed merger with the real estate company, Savola looked to acquire companies related to its core food manufacturing and sales business. All companies obviously reviewed financial statements closely to assess the financial condition of the acquired firm. Samba noted that sometimes in the banking and financial industry, strong banks will acquire banks that are in a weak financial condition in a rescue operation, often due to political reasons. In reviewing candidates for a merger, Savola engages its operations and technical team to assess the target company's operation, processes and potential fit into the business group.

The three interviewed companies use various metrics to evaluate the success of the merger. Savola evaluates the revenue growth of the sector where the acquisition occurred along with the market share and operating cost. The goals are to increase revenue, increase market share or reduce operating cost. Samba evaluated similar metrics of market share and operating cost.

Samba noted that it usually takes until the second year after a merger to evaluate its success. In the first year, there are onetime costs associated with integration costs of the merger. It usually takes until the second year to see reduced operating costs from activities such as closing and consolidating branches.

The different ways to obtain synergy in a merger were discussed with the companies. Savola looked to obtain synergy through economies of scale, as acquisitions would add to the company's shipment volume, which would allow the company to reduce freight and distribution costs. Samba also looked to obtain synergy through economies of scale and eliminating the duplication of activities. When it acquired Cairo bank, which had previously acquired United Saudi Commercial Bank, Samba was able to cut costs in Saudi Arabia by reducing the number of bank branches and 
ATMs. NCB was able to gain financial synergies in its mergers by developing a more diversified and lower risk portfolio of investments.

From the responses to the questions included in the structured interview, the following findings can be highlighted:

\section{A.Mergers to Expand to International Markets:}

One finding is that firms undertake some mergers to expand into new international markets. In doing so they are gaining the synergy of the acquired firm's knowledge of the market. In these cases, the acquiring firm saves the costs of starting up a business in the new country, gaining the necessary approvals, learning how to do business successfully in the market and building a brand in the country. This is especially true in the bank and finance industry, where the industry is closely regulated. It can be easier to acquire a company that already has all of the necessary regulatory approvals as opposed to trying to gain all of the necessary approvals to conduct business legally in the selected market. Also, building a brand is important in the banking industry, as consumers and commercial customers prefer to do business with a trusted firm. In these mergers, synergy can be gained through the acquired firm's knowledge of the market and the acquiring firm's capital. The new infusion of capital can often allow the acquired firm to grow in the market. The NCB acquisition of the Turkish bank is a good example of this type of synergy.

Even when a firm acquires a company within their own market there is the chance to create synergies through knowledge gained and transferred. In many cases, the acquired firm has certain processes in some areas that are better than the acquiring firm, so selecting the best process allows the merged firm to improve its overall processes. Also, the acquiring company usually has some processes that are better than the acquired firm's processes in some areas, which allows the company to improve the newly acquired operations. As noted by Samba in its interview, the goal is to utilize the optimum processes from both companies to produce synergy from the merger.

\section{B. Mergers to Gain Economies of Scale:}

Firms also seek and gain synergies through economies of scale. Larger businesses can often gain economies in certain business activities including manufacturing, distribution and sales. One of the goals of Samba's mergers was to gain synergies through economies of scale. In their mergers, Savola hoped to gain economies of scale in shipping and distribution activities. Economies of scale can also be achieved in the banking industry since the cost of processing checks or issuing credit cards is likely to decline on a per unit basis with increasing volume; therefore the fixed 
cost associated with these activities can be spread over a larger volume. The result is reduced costs, which makes the merged firm more profitable and more competitive in the market.

\section{Eliminating Inefficiencies:}

Another way to achieve synergy is through elimination of inefficiencies. Removing the duplication of resources can eliminate inefficiencies. In horizontal mergers, it is common for the merged company to consolidate operations, close offices and reduce staff. Samba mentioned that reducing the number of bank branches, ATMs and staff was one of the ways that they drove cost efficiencies after acquiring Cairo Bank. Samba also provided the insight that there is a delay for these cost efficiencies to show up in financial performance, since it takes time to remove the duplication of resources involved and there are one-time costs associated with removing the duplication of resources. The official also pointed out that the success or failure of a merger should not be evaluated until at least two years after the merger.

\section{Gain More Market Power:}

Firms also try to achieve synergies through an increase in market power, by controlling a larger share of the market. Discussions with all respondents implied increasing market share to be one of the motivations to enter into a merger. Savola and Samba both mentioned increasing market share as a way to judge the success of a merger. Greater market power can improve profitability through a couple of mechanisms. One such mechanism is greater monopoly pricing power in the market, which allows firms to increase prices due to reduced competition. This is one reason that major mergers have to be approved by government regulators who $\mathrm{s}$ objective is to maintain a competitive market. A second mechanism is increased buyer power over suppliers. Since the merged firm represents a greater portion of an industry's business, suppliers to the industry want the merged firm's business more, which gives the merged firm better negotiating power over suppliers. This allows the merged firm to reduce its costs and increase it profits. However, a strategic perspective could be on the supplier side as Porter (1998) identifies that the stronger the company becomes the weaker the supplier becomes thus reducing their bargaining power.

\section{E. Gain Growth:}

Growth is one of the main reasons that firms undertake mergers, as this was mentioned by all of the companies interviewed. Companies seek growth through mergers because it can allow them to gain market power, which generally leads to increased profits. Mergers are also a way to satisfy investors'/shareholders' expectations for growth. In many cases, it is difficult to grow a business in a mature market organically, so mergers are often the best way to achieve growth. 
Samba provided a perspective on the use of acquisitions as a growth strategy. Samba believed that within the same industry organic growth was less expensive than growth through acquisition because a premium had to be paid for another company's operations in the same industry. Samba believed that when trying to expand into a different industry, growth through acquisition was less expensive than organic growth because the firm had no knowledge or expertise in the new industry. Samba used this philosophy when formulating their strategic growth plans. If the company simply wanted to expand within their current industry, the focus would be on organic growth initiatives, whereas if the company wanted to grow by expanding into new industries, the focus would be on acquisitions.

\section{F. Reducing Risks}

Firms can gain synergies by reducing their overall risk through diversification and reducing their cost of capital. Generally, this is a weak form of synergy and prone to failures because it often entails firms moving into businesses outside of their core competencies. The businesses are then run without the knowledge of how to run a business successfully in that market. This leads to operational losses or subpar performance in the industry, which negates any synergistic gains from reducing the company's overall risk.

This was experienced by Savola, who acquired a real estate company, which was outside its core business of the food market. Consequently, the acquired real estate business produced subpar performance and losses, which negated any gains from reducing risk. Thus, the merger was considered to be a failure because it reduced the overall value of the firm. Due to the difficulties of creating financial synergies through diversification, there are few conglomerate mergers and few conglomerate companies.

The companies interviewed look for synergies when considering mergers and try to estimate the potential synergistic gains that could be attained in a proposed merger. The potential synergies gained depend on the industry and the characteristics of the company acquired. In the failed mergers, the firm overestimated the amount of synergy that could be gained through the merger. Savola overestimated the synergy that could be gained through the acquisition of a real estate company because the only synergy that could be gained was reduced risk and a reduced cost of capital, which was exceeded by losses resulting from Savola's lack of knowledge and experience in this non-core business. In the other failed merger, there were likely synergistic gains that could have been achieved, but Savola was unable to merge the acquired company's operating model with its existing operating models. Thus, in order to realize the potential synergistic gains that are available in a merger, firms need to be able to merge operating models. 
Different company or national cultures can interfere with the ability to merge company operations successfully. However, with the companies interviewed, this was not a major issue. Therefore, these companies have done a god job managing and overcoming cultural differences in their mergers.

\section{Conclusions}

There are several conclusions that can be derived from this research. Since many mergers fail to produce synergies or firms overestimate the synergies, it is important that companies approach acquisitions cautiously and do not overpay for acquired firms. Firms can overestimate the potential synergies of the merger and not accurately assess issues such as product line overlap and cannibalization. They can also overestimate the cash flows associated with the target firm, which leads to overvaluing the target firm. Any potential synergy that is being considered to justify a premium purchase price for a potential acquisition should be challenged using a "devil's advocate approach". It surfaced from the interviews that the interviewees agree that a successful M\&A brings positive results for the company, its employees and consumers. However, suppliers may face a bigger challenge in view of their reduced power to negotiate.

Firms should avoid unrelated mergers or conglomerate mergers. The only way to create synergy through these types of mergers is through financial synergies, which can be difficult to obtain. Often any financial synergy gained is outweighed by a decrease in performance of the acquired firm. This often occurs because the acquiring firm lacks knowledge and experience in the new type of business acquired. Thus, firms that do engage in conglomerate mergers of previously successful firms should leave the acquired firm "as is" and not try to change its management, strategies or products/services.

Firms should look for mergers that increase market power. This type of merger is the type of merger than creates synergy most automatically. A larger firm created through a merger can benefit from greater monopoly pricing power (due to reduced competition) and greater power over suppliers in the industry. A larger firm can also benefit from being able to attract and retain more talented management and employees within the industry, which can provide the firm with an additional competitive advantage.

Firms should also seek out mergers which allow the firm to acquire specialized knowledge. This is often the motivation behind mergers in technology-based industries. The company can take the technology and knowledge acquired through the 
merger and use it to advance its own product line, creating synergy. This is also a good strategy to use when entering a new international market. An existing firm in the market has knowledge of the local market, the supply base, the distributors and the governmental regulations. Acquiring a firm like this can provide synergy and save the acquiring firm from climbing the learning curve on each and all of these issues in a new international market.

Mergers motivated by economies of scale should be approached cautiously. The acquiring firm needs to carefully understand the cost drivers within its business and make sure that they will actually decline. In many industries, the cost curve become flat or even increases with increasing volume. Increased market power can create economies of scale, so firms should look for mergers that increase market power as opposed to those that simply provide an opportunity for economies of scale.

The above conclusions can be complemented with the fact that M\&A could be failures or successes. This satisfies the DiMaggio 2009 study that examined the top 10 corporate M\&A' up to 2009 and concluded that the successes and failures were evenly divided and either success or failure was achieved.

In mergers based on economies of scales, companies need to execute consolidation plans effectively in order to consolidate resources and eliminate the duplication of resources to gain cost efficiency synergies.

Companies should also approach vertical mergers cautiously as it is often difficult to gain synergy through a vertical merger. An acquiring firm needs to specifically identify areas where it faces problems or areas where it is unable to pursue attractive opportunities and understand how the vertical merger could address those areas. In some cases, the vertical merger can address these areas and synergy can be created. However, in many cases the vertical merger does not adequately address the issues and no synergy is created.

The M\&A among large firms do not result in any type of operational change; they must rely solely of financial synergies to increase the overall wealth of the firm. The value gained through financial synergies, due to a lower cost of capital, is often offset by a decrease in performance in the acquired business, as the acquiring firm does not have sufficient experience and knowledge in the acquired business. 


\section{References}

Akinbuli, S. F. (2012). Critical analysis if effect of Mergers and Acquisitions on Corporate Growth and Profitability, Global Conference on Business and Finance Proceedings, 7(1), pp. 684-697. http://search.proquest.com/ docview/1323542335? Accounted $=130572$

Berkovitch, E and Narayanan, M.P. (1993). Motives for Takeovers: An Empirical Investigation, Journal of Financial and Quantitative Analysis, 28(3), pp. 347-363. http://dx.doi.org/10.2307/2331418

Brown, G. (2005). Mergers and Acquisitions vs. Strategic alliances, Globusz Publishing, New York.

Creswell, J. (1994). Research Design - Qualitative and Quantitative Approaches, Sage Publications, Thousand Oaks, CA.

Denzin, K.M., and Lincoln, Y.S. (1994). Handbook of Qualitative Research, Sage Publications, London.

Goold, M. and Campbell, A. (1998). Desperately seeking synergy, Harvard Business Review, September-October, pp. 131-143.

Gabler, M.A. (2001). Harvard Business Review on Mergers and Acquisitions: Lessons from Master Acquires, Harvard Business School Press, Boston.

Glesne, C. and Peshkin, A. (1992). Becoming Qualitative Researchers: An introduction, Longman, New York.

Grönroos, C. (1997). Value-Driven Relationship Marketing: From Products to Resources and Competencies, Journal of Marketing Management, 13(5), pp. 407-419.

Haberberg, A. and Rieple, A. (2001). The strategic Management of Organizations, Prentice Hall, England.

Knoll, S. (2008). Cross Business Synergies. A Typology of Cross-Business Synergies and a Mid-Range Theory of Continuous Growth Synergy Realization, Gabler-Verlag, Frankfurt/Main.

McNeil, B.J. (2012). Employee benefit plans in mergers and acquisitions, Journal of Pension Planning and Compliance, 37(4), pp. 53-87. http://search.proquest.com/docview/905988260?accounted $=130572 \square$

national Commercial Bank (2001). Corporate Profile, [online], http://www.alahli.Com/en-US/About\%20Us/ Corporate\%20Profile/Pages /CorporateProfileHome_Page.aspx $\square$

Porter, M.E. (1998). Competitive Strategy, Techniques for Analyzing Industries and Competitors, The Free Press, New York.

Rahatullah, M.K. (2009). Achieving Competitive Advantage in Hybrid Relationship Businesses, Lambert Academic Publishing.

Ring, P. S., and Van-de-Ven, A.H. (1994). Development Process of Cooperative Inter-Organisational Relationships, Academy of Management Review, 19(1), pp. 90-118.

- Samba Financial Group (2011). About Samba, [online], Available at: http://www.samba.com.sa/English/ Common/HTML/aboutSamba_01_01_en.html ש

Savola Group (2011). About the Savola Group, [online], Available at: http://www.savola.com/savolae/ About_The_Savola_Group.php $\square$

Sekaran, U. and Bougie, R. (2009). Research Methods for Business, Wiley, West Sussex.

Wheelen, T. and Hunger, J. (2009). Strategic Management and Business Policy (12 ${ }^{\text {th }}$ edition), Prentice Hall, New Jersey. 


\section{Appendix I: Questionnaire.}

The questions for interviews were divided into three groups, i.e. synergy and growth, synergy and efficiency and synergy and risks. One independent question was related to the measurement of success. The respondents were requested to expand and elaborate on their answers and relate their response to synergy. They were also told that they could choose not to answer or answer a question in more or less detail. The respondents were free to inform and talk about the synergy and M\&A diverting from the questions. This was in order to know more with respect to about the issue at hand.

\section{Synergy and Growth}

1a. How do you relate a synergy to growth as a result of the M\&A of your company?

$1 \mathrm{~b}$. How did the M\&A of your company help achieve synergy related to international growth, did the M\&A help you go international?

1c. What is the role and what would you say about the international growth of your company (if it has happened) and did it result in providing any synergies?

$1 \mathrm{~d}$. Did the M\&A of your company help you achieve market power?

\section{Synergy and Efficiency}

2a. How did the M\&A in different areas of your company help you to achieve synergy related to eliminating inefficiencies?

2b. How did the M\&A of your company help you to achieve synergy related to acquiring economies of scale?

2c. Did your company identify any duplication of activities (in your or the merged or acquired firm) being carried out before, during and after the M\&A of your company?

3. How have the M\&A helped your firm reduce risks in different areas of the business, kindly elaborate?

4. How do you evaluate the success of the M\&A? 
